\title{
Serpents in jars: the snake wine industry in Vietnam
}

\author{
Ruchira Somaweera $^{1,2} \&$ Nilusha Somaweera ${ }^{2}$ \\ ${ }^{1}$ Reptile Ecology Laboratory, School of Biological Sciences, University of Sydney, Sydney NSW 2006, Australia \\ ${ }^{2}$ University of Sydney Tropical Ecology Research Facility, PO Box 441, Humpty Doo, NT 0836, Australia \\ Email: ${ }^{1}$ ruchira.somaweera@gmail.com , ${ }^{2}$ nilu.somaweera@gmail.com
}

Date of publication (online): 26 October 2010 Date of publication (print): 26 October 2010 ISSN $0974-7907$ (online) | 0974-7893 (print)

Editor: Aaron Bauer

\section{Manuscript details:}

Ms \# 02361

Received 10 December 2009

Final received 10 September 2010

Finally accepted 18 September 2010

Citation: Somaweera, R. \& N. Somaweera (2010). Serpents in jars: the snake wine industry in Vietnam. Journal of Threatened Taxa 2(11): 1251-1260.

Copyright: (C) Ruchira Somaweera \& Nilusha Somaweera 2010. Creative Commons Attribution 3.0 Unported License. JoTT allows unrestricted use of this article in any medium for non-profit purposes, reproduction and distribution by providing adequate credit to the authors and the source of publication.

Author Details: RuchiRA SOMAWEERA is a PhD research student at University of Sydney working on the ecology and conservation of freshwater crocodiles in the East Kimberley region.

Nilusha Somaweera is a research associate at the USTERF in Darwin and is assisting an array of research projects on the impact of invasive cane toads on Australian herpetofauna.

Author Contribution: Both authors contributed equally in the field surveys and writing of the manuscript.

Acknowledgements: We wish to thank Rick Shine, Nguyen Vu Khoi, Matt Wills, Simon Faithfull, Damian Goodall, Ryan Hart, Peter Ellen and Wildlife At Risk (WAR) in Vietnam for various support given during organising and conducting the surveys; Michael Pauline, Ligia Pizzato, Nguyen Quang Truong and Bryan Stuart for the open exchange of ideas, providing literature and commenting on an early draft of the manuscript; for the reviewers and editor for their valuable comments.

\section{manumusmor SYDNEY}

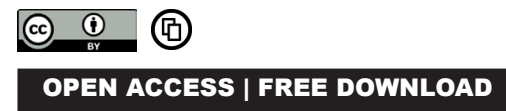

Abstract: Exploitation of snakes in Vietnam takes place for different purposes, and among them the snake wine industry is prominent but has received far less attention than other dealings, such as the pet trade. Despite widespread commercialisation there is a general lack of information about this snake trade, which makes it difficult to evaluate its magnitude and impact on snake populations. This study documents the use of snakes in snake wine in four cities in Vietnam through surveys conducted in 127 locations selling snake wine in September 2009. This study provides a list of species used along with the number of individuals observed. While none of the species involved are listed in the IUCN Red List, seven species are listed in the Vietnam Red Data Book, of which five are regulated by CITES. On the other hand, the most abundant species used in the trade, Xenochrophis flavipunctatus, is not listed in any conservation document. The popularity and economic importance of snakes in the form of snake wine demonstrates the need for the development of sustainable use programs for these species.

Keywords: Keelback, medicinal drink, rice wine, sustainable harvest, traditional medicine.

Vietnamese abstract: Ở Việt Nam, các loài rắn được khai thác cho nhiều mục đích khác nhau, trong đó mặc dù việc sản xuất rượu rắn khá nổi tiếng nhưng vẫn chưa gây được sư quan tâm nhiều như đối với các hoat động buôn bán khác, chẳng hạn như sử dụng rắn làm sinh vật cảnh. Mặc dù rượu rắn được bày bán khá phổ biến nhưng nhìn chung thông tin về hiện trạng buôn bán vẫn còn thiếu, do vậy khó có thể đánh giá được tác động của nó đến các quần thể rắn. Nghiên cứu này ghi nhận việc sử dụng rắn để ngâm rượu ở bốn thành phố lớn của Việt Nam thông qua khảo sát ở 127 địa điểm có bán rượu rắn trong tháng 9 năm 2009. Nghiên cứu này cung cấp danh sách các loài dùng để ngâm rượu cùng với số lượng cá thể quan sát được. Trong số các loài rắn dùng để ngâm rượu đã ghi nhận được, không có loài nào ghi trong Danh lục Đỏ IUCN, 7 loài ghi trong Sách Đỏ Việt Nam, 5 loài ghi trong Phụ lục CITES. Bên cạnh đó, loài phổ biến nhất dùng để ngâm rượu là Rắn nước Xenochrophis flavipunctatus, loài này không được ghi trong các tài liệu bảo tồn nào. Sự phổ biến và giá trị kinh tế của rắn trong việc sản xuất rượu rắn cho thấy cần phải xây dựng các chương trình sử dụng bền vững các loài này.

\section{INTRODUCTION}

Snakes have been used in drinks since the early days. In the Greek Hippocratic Corpus snake in wine, taken orally, was recommended for retained placenta; serpent grease was incorporated in a pessary for infertility and viper's broth was recommended for skin disease (Lawrence 1978). In recent history, societies in the East and Southeast Asian region have incorporated this practice, including Cambodia, China (including Hong Kong), Japan, Korea, Laos, Taiwan, Thailand and Vietnam (Newman 2000; Nooren \& Claridge 2001; Stuart 2004; Chao 2007). Variations of snake wine also exist in Europe, where herbalists, woodland-dwellers and natural healers use adders and calamus roots mixed with Vodka (Engelmann \& Obst 1981). In Brazil snakes are steeped in cachaça or aguardente, an alcoholic beverage made from distilled sugar cane, to produce a snake wine commonly known as 'Pinga de Cobra' (L. Pizzato pers. comm. 2009). There are reported incidents where snake wine was produced in USA by immersing baby rattlesnakes in Vodka (Reuters 2008). In certain cultures this is the equivalent of red wine, which is a 
'hot' beverage, especially for winter consumption by men (Anderson 1988). However, the method of preparation, usage and presentation of animals may differ from region to region. For example in China similar wines which utilize geckos normally do not have the body of the gecko retained in the wine like comparable Vietnamese and Laotian wines (Bauer 2009). In Taiwan, snake wine is brewed by soaking a whole poisonous snake in two gallons of Kaoliang wine and the vessel is buried deep underground for years (Anonymous 1964).

Although the tradition has existed for centuries in Asia, the trade is presumed to have grown at a startling rate since Southeast Asia opened its doors to the west and tourism has bloomed. The snake wine industry has currently developed to a stage that the products can be purchased online. Websites like www.asiansnakewine. com (from Vietnam) and www.thailandunique.com (from Thailand) market their products over the internet.

Vietnam is among the countries that utilize snakes in the 'Snake wine' industry. Snake wine, known as rượu rắn in Vietnamese, is an alcoholic beverage that includes a whole snake in a bottle of rice wine. Rice wine is the popular traditional fermented alcoholic beverage in Vietnam and is manufactured with rice Oryza sativa through physical, microbiological and biochemical operations, which result in a drink with an original alcohol content of up to $15 \%$ which can be increased up to $50 \%$ via distillation (Dung et al. 2007). However, some authors deduce that vinegar is used as the media for snake wine (e.g., Wintle 2006).

As reviewed by Sterling \& Hurley (2005), Vietnam has achieved global recognition for its unique and endemic species of organisms and a total of 199 species of snakes are reported from the country (Ziegler et al. 2008; Nguyen et al. 2009; Orlov et al. 2009a,b). In Vietnam, wild reptiles (mainly snakes) have long been utilized by people for food, medicine, magical-religious rituals, leather, pets and cosmetics (Martin 1992; Nash 1997; Compton \& Le 1998; Li \& Wang 1999; Stuart 2004; Le 2007; Nguyen et al. 2009). Currently the country is an established thoroughfare for illegal trade in wildlife, and growing urban prosperity is believed to be increasing domestic demand for wild animal products (Drury 2009). However, studies on the exploitation of wild snakes in Vietnam are largely limited to pet trafficking (Martin 1992; Nash 1997; Compton \& Le 1998; Li \& Wang 1999) and collection for food (Stuart 2004). The species involved and the level of consumption vary considerably between different regions of the country, mainly depending on the species available. These studies revealed that some species are not being used in a sustainable manner and are being commercialised illegally, generating a good deal of concern in relation to the impact on natural populations. The collection of wild reptiles for subsistence or commercialisation has been invoked as a factor contributing to the declines seen in certain species
(Gibbons et al. 2000). Despite the intensive use of snakes in the snake wine industry, however, there is a general lack of information about this trade, which makes it difficult to evaluate its magnitude and its impact on these reptiles. No information is available on the species used for the trade and the numbers in the snake wine industry.

In this paper we document the use of snakes in snake wine in four of the most touristic cities in Vietnam by cataloguing the snake species being used in the industry and the respective numbers of each species. Since information on this theme is rare, it is hoped that the data presented here may be useful in developing strategies for the sustainable use and management of these animals.

\section{METHODS}

The study took place in the Mekong Delta $\left(9^{\circ} 33^{\prime} \mathrm{N}\right.$ \& $\left.105^{\circ} 24^{\prime} \mathrm{E}\right)$, Ho Chi Minh City (HCMC; $\left.10^{\circ} 46^{\prime} \mathrm{N} \& 106^{\circ} 41^{\prime} \mathrm{E}\right)$, Hanoi $\left(21^{\circ} 1^{\prime} \mathrm{N} \& 105^{\circ} 51^{\prime} \mathrm{E}\right)$ and Halong Bay $\left(21^{0} 57^{\prime} \mathrm{N}\right.$ \& $\left.107^{\circ} 4^{\prime} \mathrm{E}\right)$ (Fig. 1). These regions and cities are inhabited by more than 30 million people: Hanoi 6.1 , Ho Chi Minh City: 6.6, Quang Ninh where Ha Long Bay is located: 1.1, and the Mekong Delta: 17.7 million each. (The General Statistics Office of Vietnam, 2008: http://www.gso.gov.vn)

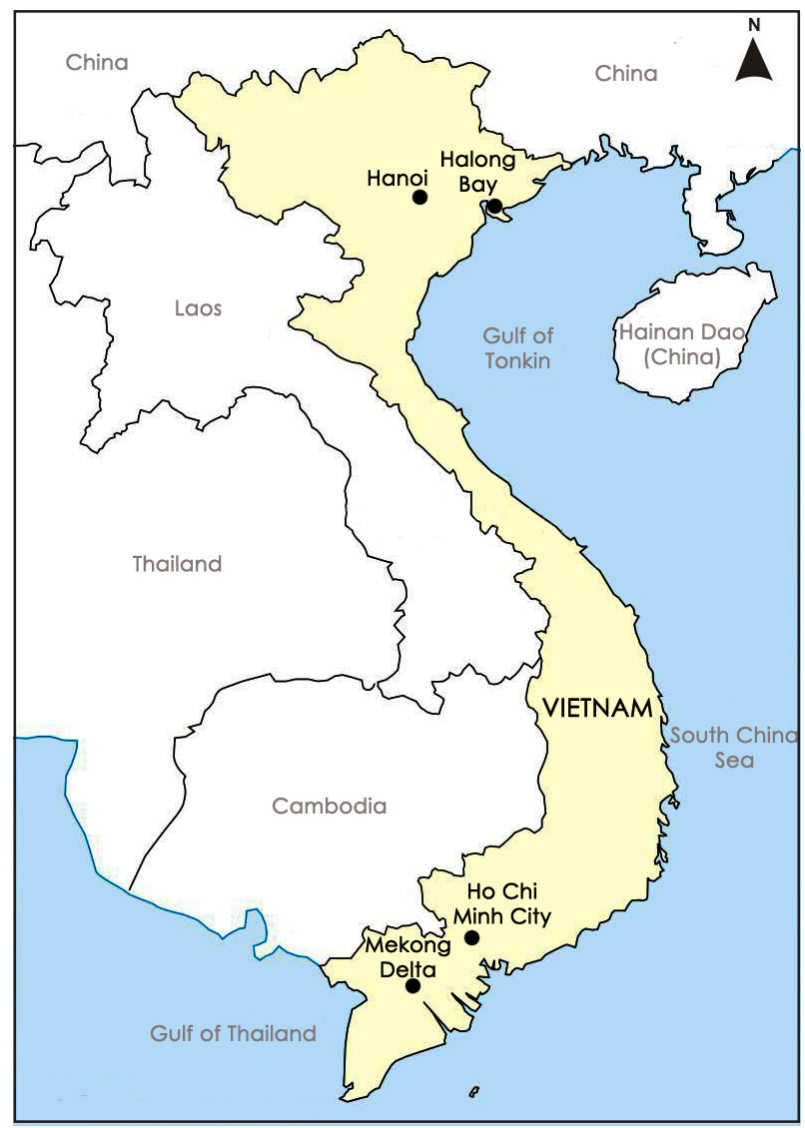

Figure 1. Map of Vietnam showing the four areas where the surveys were conducted. 
and are also popular tourist destinations for visitors. We visited open markets, shopping centres, restaurants and cafes displaying snake wine in September 2009. Most of the shops selling snake wine had the bottles displayed in front and thus could be easily located. Some shops were found by asking local residents of their whereabouts. Most approaches involved acting as a consumer interested in buying snake wine and mainly 'recording' information via photographs. In certain other places the dealers were informed about the intentions of the study and interviewed subsequently. This approach has being shown to be useful and successful elsewhere (Alves \& Filho 2007). At each place the species used were listed along with the respective numbers and sizes (as adults or juveniles) of the respective species. Species were identified to the lowest taxonomic level and whenever identification was difficult due to the visibility or orientation of the snake, it was categorised as an 'other snake'. The prices were also noted. Whenever possible, the merchants were interviewed about the origin of their goods but in most incidents the interviews were not successful since they failed to provide the required information, or the interviewees were hesitant to answer the questions.

Due to the limited geographic range the study was conducted, the opportunistic nature of the study and the taxonomic uncertainties regarding certain species, it is meaningless to conduct statistical comparisons of the number of snakes used in the snake wine industry in different cities. Thus, we examine the data mostly qualitatively while giving numerical values for comparisons.

To determine what species are known for the industry and to collect additional information, we reviewed available ethnobiological literature scattered in general books, reports and scientific publications. Due to the vast scarcity of records, we also considered references with secondary or general statements. For species we recorded during the survey, we checked the conservation status in four documents, (i) the Decree No.32/2006/ND-CP dated 30 March 2006 of the Vietnamese Wildlife Conservation Act, (ii) Vietnam Red Data Book (MST 2007), (iii) the IUCN Red List of Threatened Species version 2009.1 [referred here as international IUCN Red List) (IUCN \& SSC 2009), and (iv) the Convention on International Trade of Endangered Species of Wild Fauna and Flora - CITES (UNEP-WCMC 2009), although CITES is only relevant for international trade, and has no relevance for local (domestic) consumption.

In this work, trade values of species are presented in Vietnamese Dong (VND) and are converted to the US Dollar (USD) equivalent at the time of the study.

\section{RESULTS}

A total of 916 bottles of snake wine with 1924 snakes belonging to over 20 species were recorded from 127 locations (Table 1).

Forms of Wine: Two different forms of wine were observed, where in the most prevailing form, snakes and the other ingredients (other animals including scorpions, geckos and sometimes birds; ginseng roots and herbal seed pods, etc.) are placed inside a glass jar or bottle of traditional rice wine and allowed to steep for many months before consumption. In the less common form body fluids of the snake are extracted by slicing a snake along its venter and the blood (sometimes with the heart) and sometimes the bile is drained into a cup of rice wine and consumed fresh. We only observed the latter at the Le Mat Village in the Gia Lam District of Hanoi but it is mentioned to be common practise elsewhere (Chao 2007).

Brands: None of the dealers visited sold snake wine exclusively, but always with other food products. However, some of the restaurants in Hanoi specialized

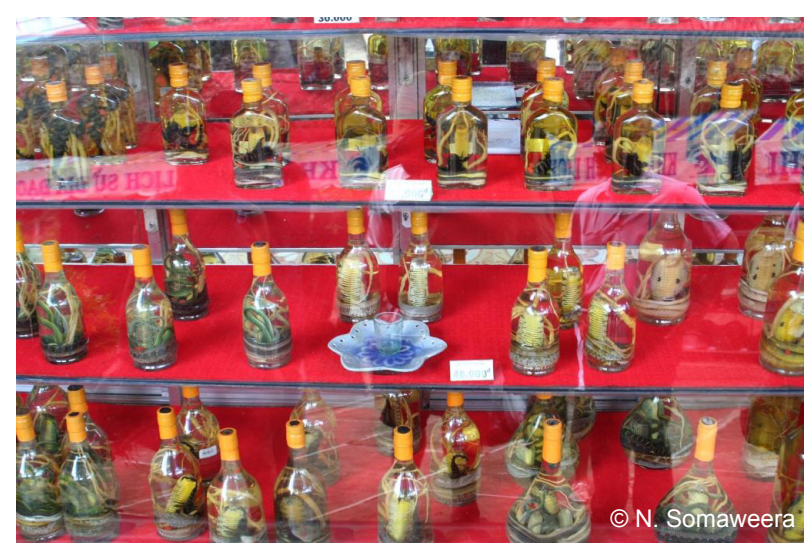

Image 1. Snake wine displayed on a shelf at a shop near $\mathrm{Cu}$ Chi Tunnels in HCMC.

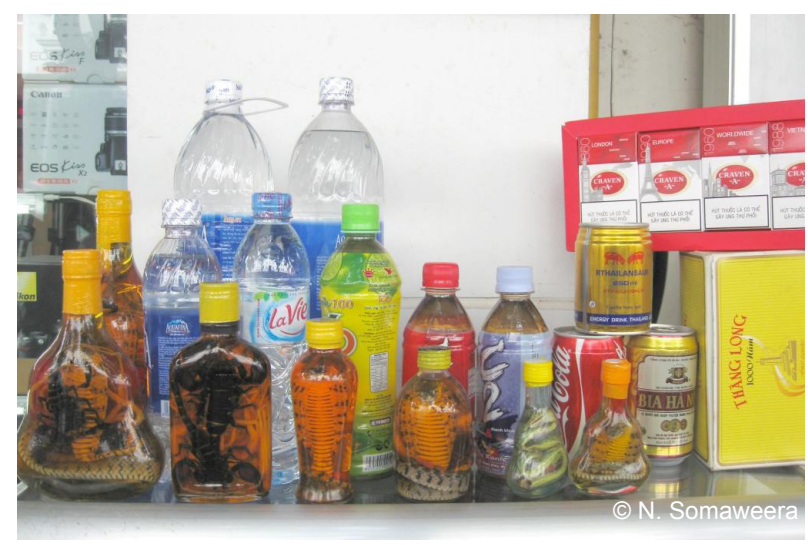

Image 2. Snake wines are among the common drinks sold on road sides in HCMC and Hanoi. 
in snake products. The bottle sizes ranged from $\sim 50 \mathrm{ml}$ to over 5l, but the most common size class was $350-750$ $\mathrm{ml}$. Depending on the size and the arrangement, a single bottle contained one to nine snakes. All bottles were made of glass and most had a characteristic yellow lid and a seal, whatever the brand. Only $28 \%$ of the bottles had labels with a brand name and were either Luckymen, Van Thanh, Phi Long (PH), Phuoc Loc, Red-labelled snake wine or Ruou Ran Luc. We did not record any bottles of the brand 'Dragon and Phoenix', said to be made using one venomous snake and a pheasant, though the same is mentioned to be very popular (Newman 2000).

Origin and destination: Snake wine was sold in outdoor markets (including road side shops) (48), indoor shops (31), restaurants (26), pubs (11), hotels (9) and airports (2) (Images 1 \& 2). In the Mekong Delta, most small-scale dealers sold home-made snake wine using snakes obtained from village markets. Most merchants

Table 1. Snake species and numbers used in snake wine in September 2009 at 127 locations in Mekong Delta (MD), Ho Chi Minh City (HCMC), Hanoi (HA) and Halong Bay (HB) in Vietnam. The number of locations visited in each area is given within parenthesis.

\begin{tabular}{|c|c|c|c|c|c|}
\hline \multirow{2}{*}{ Family and Species } & \multicolumn{5}{|c|}{ Number observed } \\
\hline & $\mathrm{MD}(26)$ & $\operatorname{HCMC~(57)~}$ & $\mathrm{HA}(36)$ & $\mathrm{HB}(8)$ & Total (127) \\
\hline \multicolumn{6}{|l|}{ Achrochordidae } \\
\hline Acrochordus granulatus Asian File Snake & & & 2 & 3 & 5 \\
\hline \multicolumn{6}{|l|}{ Boidae } \\
\hline Python bivittatus Burmese Python & 13 & & & & 13 \\
\hline \multicolumn{6}{|l|}{ Colubridae } \\
\hline Ahaetulla nasuta Long-nosed Whip Snake & 19 & 64 & 11 & 8 & 102 \\
\hline Ahaetulla prasina Oriental Whip Snake & 54 & 149 & 62 & 47 & 312 \\
\hline Boiga multimaculata Brown Cat Snake & & 1 & & & 1 \\
\hline Coelognathus radiatus Radiated Rat Snake & 1 & 2 & 1 & & 4 \\
\hline Dendrelaphis pictus Painted Tree Snake & 9 & 3 & & & 12 \\
\hline Ptyas spp. Rat Snake & 9 & 6 & 4 & & 19 \\
\hline \multicolumn{6}{|l|}{ Cylindrophidae } \\
\hline Cylindrophis ruffus Red-tailed Pipe Snake & 3 & & & & 3 \\
\hline \multicolumn{6}{|l|}{ Elapidae } \\
\hline Bungarus candidus Malayan Krait & 11 & 6 & 1 & & 18 \\
\hline Bungarus fasciatus Banded Krait & & 1 & & & 1 \\
\hline Naja kaouthia Monocellate Cobra & 34 & 47 & 51 & 31 & 163 \\
\hline Naja siamensis Indochinese Spitting Cobra & 8 & 24 & 22 & 15 & 69 \\
\hline Ophiophagus hannah King Cobra & 16 & & & & 16 \\
\hline \multicolumn{6}{|l|}{ Homalopsidae } \\
\hline Enhydris enhydris Rainbow Water Snake & 62 & 58 & 7 & 20 & 147 \\
\hline Enhydris plumbea Plumbeous Water Snake & 1 & & & & 1 \\
\hline $\begin{array}{l}\text { Enhydris spp. (those that could not be identified to } \\
\text { species level) }\end{array}$ & 39 & 21 & 14 & 14 & 88 \\
\hline \multicolumn{6}{|l|}{ Natricidae } \\
\hline $\begin{array}{l}\text { Xenochrophis flavipunctatus Yellow-spotted } \\
\text { Keelback }\end{array}$ & 230 & 331 & 265 & 86 & 912 \\
\hline \multicolumn{6}{|l|}{ Viperidae } \\
\hline $\begin{array}{l}\text { Green Pit-vipers (either Cryptelytrops albolabris, } C \text {. } \\
\text { macrops, Viridovipera stenjnegeri or V. vogeli) }\end{array}$ & 21 & 5 & 9 & 3 & 38 \\
\hline Total & & & & & 1924 \\
\hline
\end{tabular}


interviewed in HCMC and Hanoi revealed that they obtained the products regularly from middlemen, thus they do not know the correct origin of the product. Some presumed they are from southern Vietnam. Two merchants informed us that some of their products are from Thailand and China, but this could not be verified. However, most dealers tended to omit information, probably since they knew that some of the species are protected by environmental laws.

According to $84 \%$ of the merchants interviewed, locals buy more snake wine than tourists. Most tourists from western countries we interviewed indicated that they would buy a bottle of snake wine as a souvenir to take back rather than to consume but were concerned about the quarantine rules in their countries.

Species used: A total of over 20 species of snakes were observed to be sold in snake wine, of which 16 species were identified to species level (Table 1). Of the total of 916 bottles, $36 \%$ had more than one species of snake put together with the main subject placed in the middle and the other or others hung on the either side of its mouth or placed in the bottom of the bottle in a coiled arrangement as the base for the main subject. According

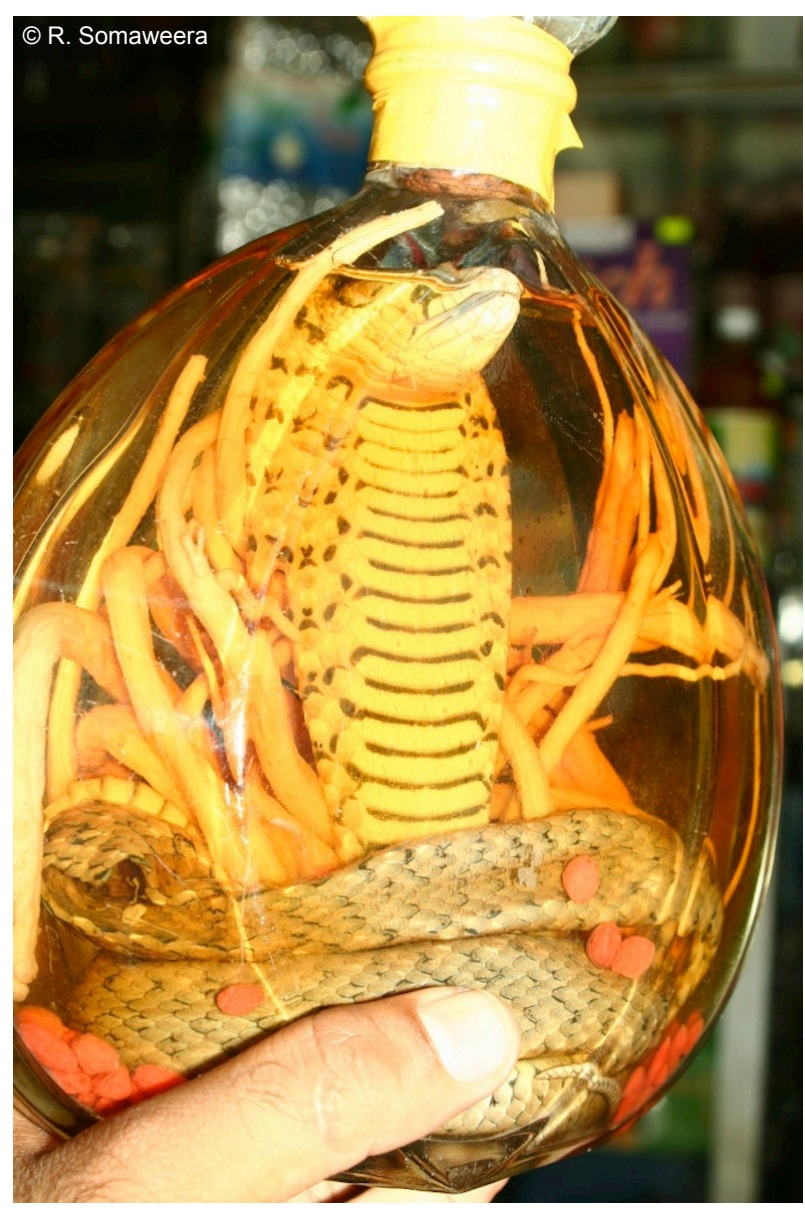

Image 3. A keelback snake with the neck expanded in the form of a hood.

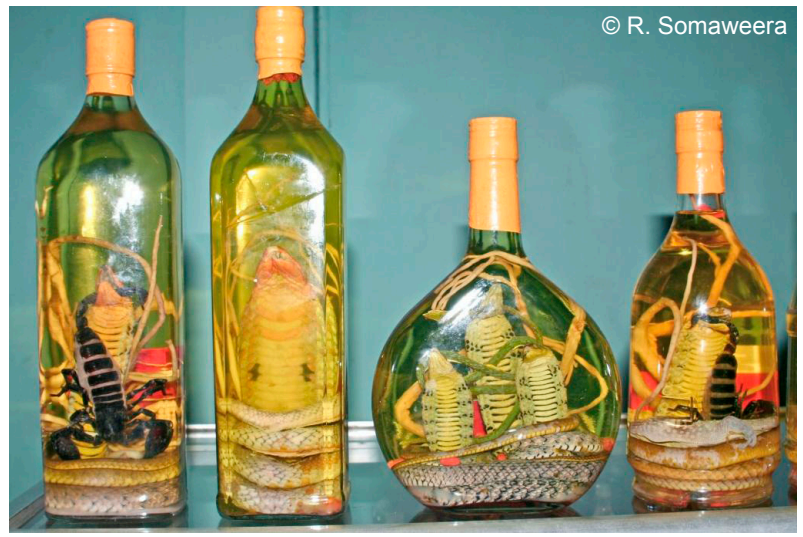

Image 4. The vender persuaded that all these are cobras whereas only the second from left actually is. The rest are keelback snakes.

to the dealers, venomous snakes are preferred in the trade over non-venomous species in the belief that the snake poison will dissolve in the liquor and add more medicinal value.

Keelbacks: The Yellow-spotted Keelback Xenochrophis flavipunctatus was the most commonly used species in snake wine, accounting for $47.4 \%$ of the snakes found. The specimens used ranged from $\sim 20 \mathrm{~cm}$ to $\sim 100 \mathrm{~cm}$ in total length. The neck of the snake (and in some other water snakes) were stretched to give the appearance of a cobra and in certain individuals the dark-coloured free margin of the ventral scales of the anterior body were further marked with a black marker pen to give prominence (Image 3). The owners strongly argued that these were cobras, probably not due to misidentification but since bottle with cobras are more expensive than most other snakes (Image 4). Keelbacks were often kept individually in bottles and sometimes with a green vine snake or a black scorpion hung from its mouth. Occasionally three specimens were arranged side by side in flat and wide bottles. Rarely, they were seen used as a decoration in large jars with cobras.

The keelback is a common species throughout Vietnam (Nguyen et al. 2009). The earlier records of $X$. piscator from Vietnam are now referred to as $X$. flavipunctatus (Vogel \& David 2006; Nguyen et al. 2009) since the former is only found throughout India, Pakistan, Nepal, Bangladesh, much of Myanmar, northern and northwestern Thailand, northwestern Laos and barely entering China (Vogel \& David 2006). Xenochrophis flavipunctatus is not listed in the Vietnam Red Data Book, the international IUCN red list. Also, this species is not regulated by the CITES.

Cobras: King Cobras Ophiophagus hannah were sold only in two shops and the owners avoided revealing the source (Image 5). The other smaller cobras (Naja kauthia and $N$. siamensis) were among the most expensive species sold and the larger specimens were mostly placed 


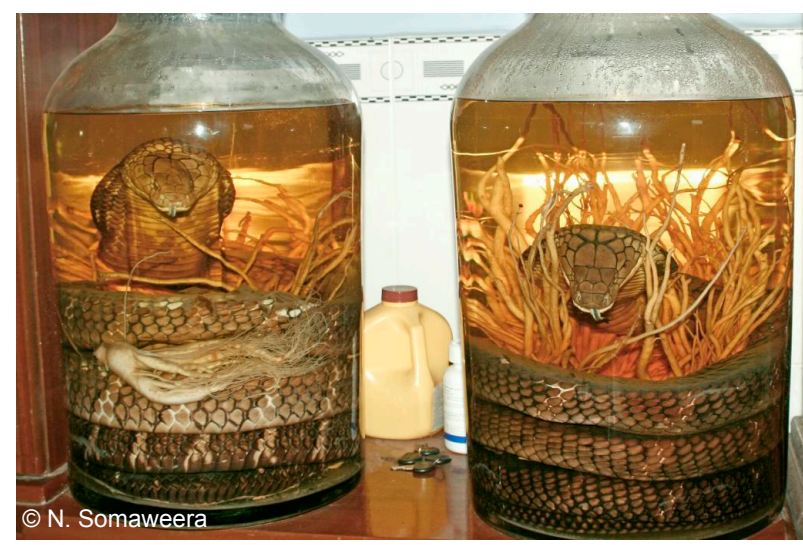

Image 5. Both these King Cobras were estimated to be over $2 \mathrm{~m}$ long.

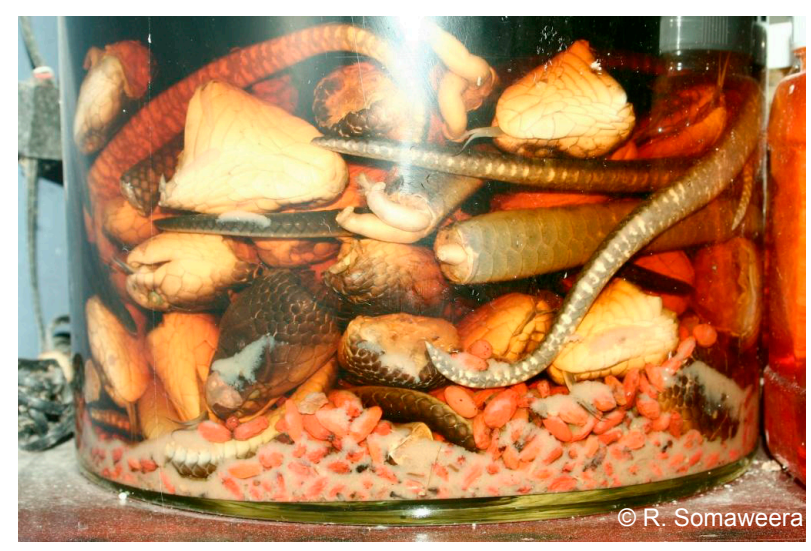

Image 6. Cobra heads, tails and hemipenises preserved in wine in Mekong Delta.

with 2-4 other species of snakes and sometimes also with Tokay Geckos (Gekko gekko), scorpions, sea horses and birds. We did not observe any specimens that could be considered as Naja atra, though the species is present in the country. One vender separately sold cobra heads, tails and hemipenises preserved in wine (Image 6).

According to the Vietnamese Wildlife Conservation Act, the usage of wild-caught Naja species in the trade is restricted while the use of wild-caught King Cobras is prohibited. All three species of cobras observed by us, viz., O. hannah, $N$. kauthia and $N$. siamensis, are included in Appendix II of CITES while O. hannah is listed as Critically Endangered and $N$. kaouthia as Endangered in the 2007 Vietnam Red Data Book.

Kraits: Bungarus fasciatus was only seen on one occasion whereas white and black banded species (possibly Bungarus candidus) was infrequently seen in large bottles assorted with other snakes. Probably due to the inability of expanding the neck as a hood, kraits were not observed to keep individually as the core subject, but always as a decoration in a bottle with another 'main' snake, frequently a Naja specimen.
Bungarus fasciatus is listed as Endangered in Vietnam but no Bungarus species from Vietnam are listed in CITES.

Green whip snakes and tree snakes: Whip snakes or vine snakes of the genus Ahaetulla were the second most commonly used in the industry. Most specimens were used as decorations in bottles with keelbacks and cobras while the smallest specimens $(\sim 25 \mathrm{~cm})$ and the largest ones $(\sim 150 \mathrm{~cm})$ were sold independently. Tree snakes or bronze-back snakes of the genus Dendrelaphis were uncommon (12 specimens) but were always used as a decorative.

None of these colubrids from Vietnam are listed in CITES.

Homalopsid water snakes: Water snakes of the genus Enhydris were the most commonly available snakes in pet shops and open markets (Stuart 2004; Somaweera pers. obs. 2009) but were uncommon in the snake wine industry. Other than 147 specimens of $E$. enhydris and one specimen of $E$. plumbea, none of the other specimens potentially referable to Enhydris could be identified to species level.

None of these homalopsids from Vietnam are listed in any of the conservation documents.

Vipers: Identification of pit-vipers placed inside jars was difficult due to the high diversity of species in Vietnam and the many similarities of certain species. The specimens observed could be any of Cryptelytrops albolabris, $C$. macrops, Viridovipera stenjnegeri or V. vogeli. Pit-vipers were used as decorations in large jars with cobras and King Cobras.

No viperids from Vietnam are listed in CITES.

Pythons: The only locations where we observed pythons in snake wine was the Dong Tam Snake Park in Mekong Delta. These juvenile Python bivittatus specimens were said to be sourced from the farm itself. Pythons (Python bivittatus and $P$. reticulatus) had uses beyond their utilization in snake wine and were observed as pets in 13 locations in the Mekong Delta. According to villagers, they are also in high demand for meat, skin and the oil. The oil is used both as food and as a skin moisturiser and sunscreen.

Both species of pythons are listed as Critically Endangered in Vietnam and are listed in the Appendix II of CITES. Furthermore, the trade of wild-caught individuals of both species is restricted according to the Vietnamese Wildlife Conservation Act.

Other snakes: Less than five individuals of each Coelognathus radiatus, Ptyassp. (probably P. mucosa and P. korros), Boiga multimaculata, Acrochordus granulatus and Cylindrophis ruffus were recorded during the survey. They were always used as decoratives.

Both Ptyas korros and P. mucosus are listed as Endangered in Vietnam while Coelognathus radiata is considered to be Vulnerable. Furthermore, Ptyas mucosa is listed in the Appendix II of CITES. 
Price: The price depended on both the size of the bottle and the species included. A bottle of less than $100 \mathrm{ml}$ with a single $X$. flavipunctatus or a Ahaetulla sp. was 30,000D ( US\$2), while a $375 \mathrm{ml}$ bottle with a either of these two species ranged from $60,000 \mathrm{D}$ to $135,000 \mathrm{D}$ ( US\$ 3-8). A 300-500ml bottle with a Naja sp. ranged from 400,000- 1,000,000D ( US\$ 22-56) and a bottle over 11 with a larger cobra with few other types of animals would go up to $3,000,000 D$ ( US\$ 170). In general branded wine was observed to be more expensive than equivalent unbranded bottles.

Uses: It is presented on the bottles that snake wine possesses medicinal qualities and cure conditions from farsightedness to hair loss, lumbago, sweating of limbs, general fatigue, migraine headaches, rheumatism, and neurasthenia. Some are also mentioned to increase sexual performance. Most were recommended to be used twice a day, each time a small cup before meals, while few mentioned that people of all ages and both sexes, including pregnant women, can drink them regularly in all four seasons.

\section{DISCUSSION}

One of the significant finding of this study was the high taxonomic diversity of snakes involved in the snake wine trade. The usage of snakes seems to be a matter of preference than availability as species commonly dealt in the markets in southern Vietnam, including Homalopsis buccata and Xenopeltis unicolor were not observed by us in snake wine. Venomous species, especially elapids, were observed to be preferred thus more targeted by the dealers. The only other Vietnamese references we could find on other species of snakes found in snake wine other than for those species recorded during the current study was the Jerdon's Pit-viper Protobothrops jerdoni from the high altitude Hoang Lien Son range (Sterling et al. 2006). However, the Horned Pit-viper Triceratolepidophis sieversorum was first discovered as a preserved specimen in the rice wine collection of a local healer in Quang Binh province (Ziegler 2004) and Truong et al. (2009) mention of the rare use of sea snakes in snake wine. Although we did not find any dealers specialized to snake wine, it was the main product sold in some of the smaller shops we visited. Hendrie (2000) mentions that a business card from a dealer in Ben Chuong Duong in HCMC stated "specialized in selling and buying all kinds of animals. Especially: Poisonous snakes, snake wine".

Unfortunately, unlike certain other reptile groups within Vietnam for which the trade has being investigated (e.g. turtles: Jenkins 1995; Le \& Broad 1995; Lehr 1997; Hendrie 2000) hardly any long-term data is available on the level of wild snake exploitation in Vietnam except for a few occasional reports of localised works (e.g. Stuart 2004). While most of the snakes in the industry are known to be sourced from the wild, a portion of venomous snakes, especially King Cobras and cobras comes from snake farms in Vinh Phuc, Thanh Hoa, Nghe An, Ho Chi Minh City, Soc Trang, Vinh Long and Kien Giang provinces (N. Truong pers. comm. 2009; Truong et al. 2009). A growing population of almost 80 million people, the flowering of an open market economy, and accompanying increases in hunting, fire, overgrazing, drainage, clear-cutting, and conversion of wild habitats to agriculture lands, threatens certain rare and commercially valuable species of wildlife (MacKinnon 1997). There is also a market for Vietnamese snakes in other countries. In early 1998, a Vietnamese government decree banned the sale of snakes and cats to China, linking it to an endemic rise in the rat population, particularly in Hanoi. The Chinese government places similar restrictions on the killing of snakes, yet snake wine remains popular in all regions. We did not interview any tourists from East Asian region thus do not have information on the demand for snake wine among tourists from that region. However, it is known that Chinese and Korean tourists buy snake wine in Hanoi and Ha Long Bay (N. Truong pers. comm. 2009).

There are several reasons as to why snake wine is so popular in Southeast and East Asia, especially in Vietnam. The ingredients needed to produce snake wine are available locally and throughout the year and are cheap. Strong and widely held beliefs of their benefits further promote these drinks. Though no work has scientifically looked into the actual benefits of snake wine, they have been widely mentioned to be a zootherapeutic medicinal drink (Marshall 1979) or an aphrodisiac drink (Willoughby 2008). Furthermore, snake blood and bile in wine is considered as a rejuvenating drink (Hopkins et al. 2004). The benefits, especially the medicinal values, have been trusted by Asians (e.g. Maomao 1995; Sterling et al. 2006), as well as westerners (e.g. Ingersoll 1986). In addition to the benefits mentioned on labels, Engelmann \& Obst, (1981) mentioned the use of snake wine to increase sexual potency and as a medicine for leprosy. Snake wine (sometimes boiled to a pulp) is also used as a febrifuge by Chinese (Gray 2003). The custom of using snake wine is much embedded in the East Asian cultures. This tradition is even followed by certain individuals living outside the region. Berger (2004) mentions that rheumatic Chinese elders in New York used to buy snakes, steep them alive in rice wine mixed with Chinese herbs and rubbed the resulting liniment on ailing body parts. Moreover, it is also used as an ingredient in Chinese cuisine where nuts, fungus and wolfberries are stewed in snake wine to prepare dishes (Newman 2000).

In the Vietnamese culture, snakes symbolise 'heat' and masculinity and are associated with male potency (Drummond \& Rydstrom 2004). In some areas snake meat and snake wine are only offered in special restaurants where females do not visit and in certain groups of people 


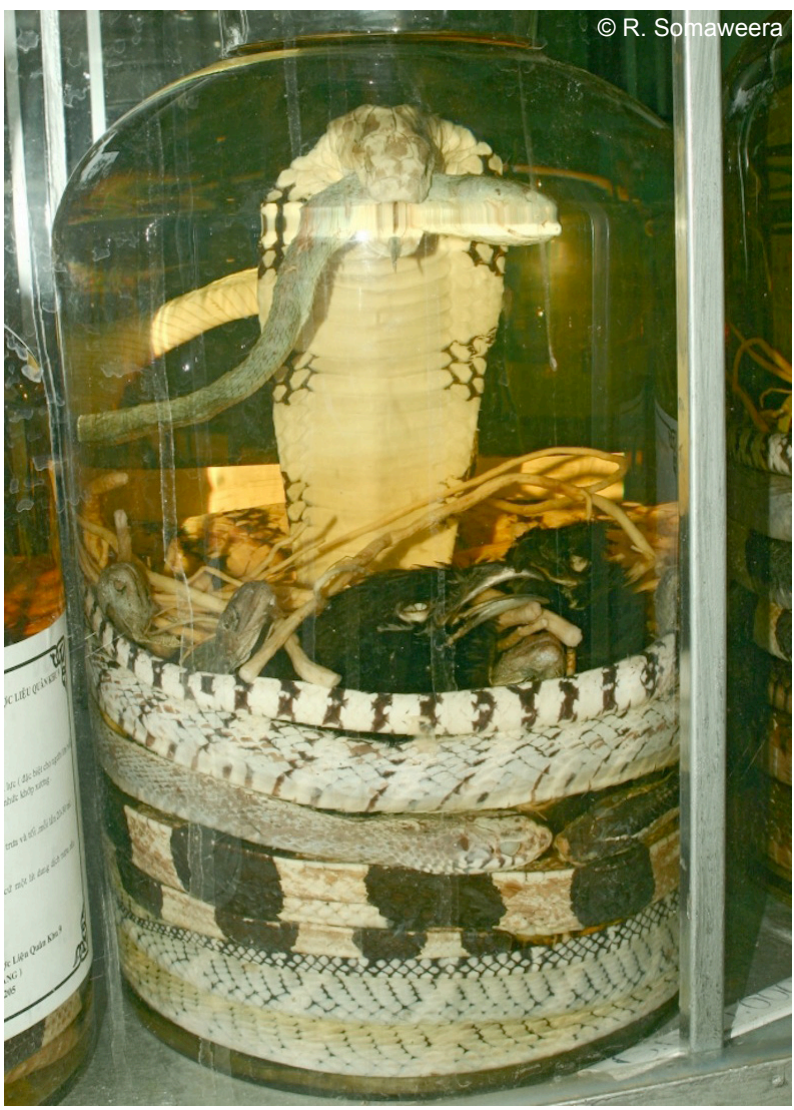

Image 7. An over 51 bottle containing a King Cobra as the main subject with a pit-viper hanging from the mouth. The base contains rat snakes and a Banded Krait while Tokay Geckos, birds and ginseng roots are also used as items. In certain Chinese cultures it is considered that Indo-Chinese rat snakes, cobras and kraits will benefit the upper, middle and lower portions of the body, respectively.

such as Thinh Tri females virtually never drink snake wine (Drummond \& Rydstrom 2004). Certain cultures also believe that different species of snakes benefit different parts of the body. In certain Chinese cultures it is thought that Indo-Chinese rat snakes, cobras and kraits will benefit the upper, middle and lower portions of the body, respectively (Marshall 1979). This belief could be a reason why some snake wine bottles have all these species together (Image 7). Moreover certain parts of the snake is supposed to have different uses such as snakepenis wine believed to be a 'manhood enhancer' while snake-gallbladder wine is considered to improve eyesight (Zhang 2008). The bile of a snake is also drunk mixed with some rice wine and consumed before the meal as an invigorating beverage and appetite stimulant and in the treatment of diseases. Snake bile (sometimes mixed with snake wine) is used for whooping cough, rheumatic pain, high fever, infantile convulsion, hemiplegia, haemorrhoids, gum bleeding, and skin infections (Dharmananda 1997). Many ancient Chinese medical books described the therapeutic effects of treating rheumatism, hemiplegia, neuralgia and muscle poliomyelitis with parts of snakes including gall bladder and liver (Guo et al. 1996 as cited by Zhou \& Jiang 2005). Though we could not find any literature pertaining to the use of snake wine as a medicine for snakebite in Asia, the natives of Rio, Brazil, preserve fangs of Rattlesnakes in cachaca, which is drunk in case of snake bite (Kanner 1928; Russell 1980).

The dealers prefer venomous species in the snake wine in the belief that the snake poison will dissolve in the liquor and add more medicinal value. However, venom, being predominantly proteins, is denatured in the presence of alcohol by two processes: disruption of the native state and induction of an a-helical conformation (Hirota et al. 1997; Hirota-Nakaoka \& Goto 1999). The preference of the people to consume venomous snakes has also been shown in China (Liu 2001 as cited by Zhou \& Jiang 2005).

The present work indicates that $X$. flavipunctatus and Ahaetulla spp. are the two most widely sold taxa in the snake wine industry, and are thus more susceptible to overexploitation. The most widely used snake in the snake wine industry, $X$. flavipunctatus, was also one of the most commonly dealt species as human food in the Mekong Delta and animal food in snake farms where they were used as food for King Cobras, cobras and kraits. The high volume of wild snake meat consumed in southern Vietnam appears to reflect a preference, rather than a necessity since avian and mammalian meat was commonly available and cheaper. Three vendors in an open market in the buffer zone of the $U$ Minh Thuong National Park (UMTNP) in the Mekong Delta sold $X$. flavipunctatus as food and the daily amount of keelbacks sold was estimated at $45-110 \mathrm{~kg}$, all of which were said to have been collected from around UMTNP. According to the fisherman $X$. flavipunctatus is available throughout the year and by placing the nets few inches above water, they could substantially increase the days' catch by trapping water snakes in the nets. When catching snakes with rods and lures, fish was used as the bait for water snakes (Xenochrophis and other species) while live toads or frogs were said to be used to specifically target cobras. Body size, clutch size, mature age and distribution have been identified as factors determining the severity of overexploitation on snake populations (Luiselli \& Capizzi 1997; Shine et al. 1999a; Reed \& Shine 2002; Zhou \& Jiang 2005). Hence it is of conservational importance that these aspects are studied on the species commonly used in the trade.

The commercialisation of snakes raises concerns in relation to the conservation of these reptiles, especially for the highly exploited species. The only legal obstacle for snake meat and wine consumption in Vietnam comes through wildlife conservation laws while laws on food do not control these trades. The Vietnamese government did not put restrictions against eating snakes or consuming snake wine after any outbreak of SARS (Severe Acute 
Respiratory Syndrome) in 2003, whereas neighbouring China prohibited eating snakes after the SARS outbreak the same year (Zhou \& Jiang 2005). However in China, people were reported to revert to their habit of eating snakes as the fear of SARS was fading (Zhou \& Jiang 2005). A thorough revision on biological risks associated with consumption of reptile products (Magnino et al. 2009) does not include incidents associated with snake wine. However, human sparganosis, caused by (among others) the ingestion of plerocercoid larvae in raw or insufficiently cooked meat of reptiles (or amphibians), has been reported from Vietnam (Beaver et al. 1984; Magnino et al. 2009).

Conservation efforts to date in Vietnam have focused on emergency measures such as the confiscation of illegally traded animals and animal parts (Le 2007). Yet, none of the vendors admitted a decrease in availability of any species. A 2009 follow-up survey to a study conducted in UMTNP in 2000 (Stuart 2004) recorded most of the species recorded during the earlier study despite the species being heavily exploited for almost a decade (Goodal \& Faithfull 2010). Similar trends were recently seen in turtles of Cat Tien National Park where illegal trade has prevailed since 1989 (Le 2007). However, despite the need, it is almost always difficult to evaluate the degree of "sustainability" of exploitation of wild populations (Shine et al. 1999a,b). Even under ideal circumstances, where the resource in question is clearly delimited and easily quantified, it can be difficult to establish the degree of harvesting which will allow indefinite persistence of the resource at levels that are "acceptable" ecologically, economically, aesthetically, or genetically (e.g., Choquenot 1996). The portion of the trade identified during our brief study is extremely small to allow conclusive statements to be made on the sustainability of the practice. Lack of data on the population sizes of snakes in the region further preclude predictions on the impact of snake wine or the snake meat industries on wild populations of snakes. However, judging from the high levels of exploitation and trade observed during this study, maintenance of viable populations of most snakes under current harvesting levels looks unlikely.

\section{REFERENCES}

Alves, R.R.N. \& G.A. Filho (2007). Commercialization and use of snakes in North and Northeastern Brazil: implications for conservation and management. Biodiversity and Conservation 16: 969-985.

Anderson, E.N. (1988). The Food of China. CT Yale University Press, New Haven, xvi+263pp.

Anonymous (1964) Free China Review, Volume 14. Kwang Hua Publishing Co., Taipei, Taiwan, 88pp.

Bauer, A.M. (2009). Geckos in traditional medicine: forensic implications. Applied Herpetology 6: 81-96.

Beaver, P.C., R.C. Jung \& E.W. Cupp (1984). Clinical Parasitology. Lea \& Febiger, Philadelphia, U.S.A., 825pp.

Berger, M. (2004). Meyer Berger's New York. Fordham University
Press, New York, 322pp.

Chao, V. (2007). Ninety Days in Guangzhou. Trafford Publishing, Victoria, Canada, 190pp.

Choquenot, D. (1996). The ecological basis of wildlife harvesting, pp 48-59. In: Bomford, M. \& J. Caughley (eds.). Sustainable use of Wildlife by Aboriginal Peoples and Torres Strait Islanders. Australian Government Printing Service, Canberra, ix+216pp.

CITES Secretariat (2009). Convention on International Trade of Endangered Species of Wild Fauna and Flora, http://www. cites.org/. Downloaded on 15 October 2009.

Compton, J. \& Q.H. Le (1998). Borderline: an assessment of wildlife trade in Vietnam. WWF Indochina Programme, Hanoi, Vietnam.

Dharmananda, S. (1997). The Medicinal Use of Snakes in China. $<$ <ttp://www.itmonline.org/arts/snakes.html>. Downloaded on 25 October 2009.

Drummond, L. \& H. Rydstrom (2004). Gender Practices in Contemporary Vietnam, Singapore University Press Pte Ltd, Singapore, 316pp.

Drury, R. (2009). Reducing urban demand for wild animals in Vietnam: examining the potential of wildlife farming as a conservation tool. Conservation Letters 2: 263-270.

Dung, N.T.P., F.M. Rombouts \& M.J.R. Nout (2007). Characteristics of some traditional Vietnamese starch-based rice wine fermentation starters (men). Lwt-Food Science and Technology 40(1):130-135.

Engelmann, W. \& F.J. Obst (1981). Snakes: Biology, Behaviour and Relationship to Man. Exeter Books, New York, 222pp.

Gibbons, J.W., E.S., David, T.J. Ryan, K.A. Bushlmann, T.D. Tuberville, S.M. Metts, J.L. Greene, T. Mills, Y. Leiden, S. Poppy \& C.T. Winne (2000). The global decline of reptiles, déja'vu amphibians. BioScience 50: 653-666.

Goodall, D. \& S. Faithfull (2010). U Minh Thuong National Park - Kien Giang Province, Vietnam Amphibian and Reptile Survey 7th - 21st September 2009. Wildlife At Risk, Vietnam, 40pp.

Gray, J.H. (2003). China: A History of the Laws, Manners and Customs of the People. Dover Publications, New York, 992pp.

Guo, Y., X. Zou \& Y. Chen (1996). Tentative survey on sustainable use of medicinal animals. In: China International Cooperation Committee of Environment and Development (ed.), Protect the Biodiversity of China. China Environmental Science Press, Beijing [in Chinese].

Hendrie, D.B. (2000). Compiled Notes on the Wildlife Trade in Vietnam. <http://nytts.org/Vietnam/tradenotes_05-00.pdf>. Downloaded on 23 October 2009.

Hirota, N., K. Mizuno \& Y. Goto (1997). Cooperative a -helix formation of $\beta$-lactoglobulin and melittin induced by hexafluoroisopropanol. Protein Science 6:416-421.

Hirota-Nakaoka, N. \& Y. Goto (1999). Alcohol-induced denaturation of $\beta$-lactoglobulin: a close correlation to the alcohol-induced a-helix formation of melittin. Bioorganic \& Medicinal Chemistry 7(1):67-73.

Hopkins, J., A. Bourdain \& M. Freeman (2004). Extreme Cuisine: The Weird \& Wonderful Foods That People Eat. Periplus Editions (HK) Ltd., Singapore, ix+352pp.

Ingersoll, R. (1986). Story of Ernest Hemingway's Far East Trip, In: Bruccoli, M. (ed.). Conversations with Ernest Hemingway. University Press of Mississippi, Jackson, MS, 204pp.

IUCN \& SSC. (2009). IUCN Redlist of Threatened Species <http://www.iucnredlist.org/>. Downloaded on 15 October 2009.

Jenkins, M.D. (1995). Tortoises and Freshwater Turtles: The Trade in Southeast Asia. TRAFFIC International, UK, 48pp.

Kanner, L. (1928). Folklore of The Teeth. The Macmillan Company, New York, xii+316pp.

Lawrence, C. (1978). The healing serpent-the snake in medical 
iconography. Ulster Medical Journal 47(2): 134-140.

Le, D.D. \& S. Broad (1995). Investigations into Tortoise and Freshwater Turtle Trade in Vietnam. IUCN Species Survival Commission, IUCN, Gland, Switzerland and Cambridge, UK, $48 p p$.

Le, M. (2007). Conservation of turtles in Vietnam: a survey of Cat Tien National Park. Oryx 41(4): 544-547.

Lehr, E. (1997). Untersuchungen zum Schildkrötenhandel in Vietnam zwischen 1993 und 1996. Zoologische Gesellschaft für Arten- und Populationsschutz 13(2):12-19

Li, W. \& H. Wang (1999). Wildlife trade in Yunnan Province, China, at the border with Vietnam. TRAFFIC Bulletin 18(1): 21-30.

Liu, M. (2001). Status evaluation of snake resources in Liaoning Province, pp. 56-60. In: China Wildlife Conservation Association (ed.), Proceedings to the Workshop on Resources Conservation and Sustainable Use in Snakes. China Wildlife Conservation Association, Beijing. [in Chinese].

Luiselli, L. \& D. Capizzi (1997). Influences of area, isolation and habitat features on distribution of snakes in Mediterranean fragmented woodlands. Biodiversity Conservation 6(10) 1339-1351.

MacKinnon, J. (ed.) (1997). Protected Areas Systems Review of The Indo-Malayan Realm. Canterbury, U.K.: Asian Bureau for Conservation Limited, Canterbury UK, 198pp.

Magnino, S., P. Colin, E. Dei-Cas, M. Madsen, J. McLauchlin, K. Nöckler, M.P. Maradona, E. Tsigarida, E. Vanopdenbosch \& C.V. Peteghem (2009). Biological risks associated with consumption of reptile products. International Journal of Food Microbiology 134: 163-175.

Maomao, (1995). Deng Xiaoping: My Father. Basicbooks, New York, xvii+498pp.

Marshall, M. (1979). Beliefs, Behaviours, \& Alcoholic Beverages: A Cross-Cultural Survey. University of Michigan Press, Ann Arbor, 490pp.

Martin, E.B. (1992). Observations on wildlife trade in Vietnam. TRAFFIC Bulletin 13(2): 61-67.

Ministry of Science and Technology (2007). Vietnam Red Data Book, Part I. Animals. Hanoi: Natural Science and Technology Publishing House.

Nash, S.V. (1997). Fin, Feather, Scale and Skin: Observations on the Wildlife Trade in Lao PDR and Vietnam. Report of the TRAFFIC Southeast Asia, Malaysia, 52pp.

Newman, J.M. (2000). Snake as Food and Medicine Flavour and Fortune, Institute of advancement of the Chinese cuisine 7(2): 13-29.

Nguyen, V.S., T.C. Ho \& Q.T. Nguyen (2009). Herpetofauna of Vi-etnam. Edition Chimaira, Frankfurt am Main, 768pp.

Nooren, H. \& G. Claridge (2001). Wildlife Trade in Laos: The End of The Game. Netherlands Committee for IUCN, Amsterdam, 304pp

Orlov, N.L., S.A. Ryabov \& T.T. Nguyen (2009a). Two new species of genera Protobothrops Hoge et Romano-Hoge, 1983 and Viridovipera Malhotra et Thorpe, 2004 (Ophidia: Viperidae: Crotalinae) from karst region in northeastern Vietnam. Part I. Description of a new species of Protobothrops genus. Russian Journal of Herpetology 16(1): 69-82.
Orlov, N.L, V.E. Kharin, B.A. Natalia, T.T. Nguyen \& Q.T. Nguyen (2009b). A new genus and species of Colubrid snakes (Squamata, Ophidia, Colubridae) from South Vietnam (Lam Dong Province). Russian Journal of Herpetology 16(3): 228-240.

Reed, R.N. \& R. Shine (2002). Lying in wait for extinction: ecological correlates of conservation status among Australian elapid snakes. Conservation Biology 16(2): 451-461.

Russell, F.E. (1980). Snake Venom Poisoning. Scholium International, Inc. New York, 562pp.

Shine R., Ambariyanto \& P.S. Harlow (1999a). Reticulated pythons in Sumatra: biology, harvesting and sustainability. Biological Conservation 87: 349-357.

Shine, R., Ambariyanto, P.S. Harlow \& Mumpuni (1999b). Ecological Attributes of Two Commercially-Harvested Python Species in Northern Sumatra. Journal of Herpetology 33(2): 249-257.

Sterling, E.J. \& M.M. Hurley (2005). Conserving Biodiversity in Vietnam: Applying Biogeography to Conservation Research, Proceedings of the California Academy of Sciences Supplement I 56(9): 98-118.

Sterling, E.J., M.M. Hurley \& M.D. Le (2006). Vietnam: A Natural History. Yale University Press, New Haven, 423pp.

Stuart, B.L. (2004). The Harvest and Trade of Reptiles at U Minh Thuong National Park, Southern Vietnam, TRAFFIC Bulletin 20(1): 25-34

Reuters, T. (2008). Extra bite - Texan faces charges over snake vodka, <http://www.reuters.com/article/oddlyEnoughNews/ idUSN2635178620080327>. Downloaded on 27 March 2008.

Truong, N.Q., N.V. Sang, D.T. The \& N.T. Tao (2009). Diversity of venomous snakes in Vietnam (in Vietnamese). Proceedings of the 1st National Conference on Vietnamese Herpetology. Hue, November 2008, 159-168pp.

Vogel, G. \& P. David (2006). On the taxonomy of the Xenochrophis piscator complex, pp. 241-246. In: Vences, M., J. Köhler, T. Ziegler \& W. Böhme (eds.). Herpetologia Bonnensis II. Proceedings of the 13th Congress of the Societas Europaea Herpetologic.

Willoughby, R. (2008). North Korea: The Bradt Travel Guide. The Globe Pequot Press Inc., Guilford, Conecticut, 230pp.

Wintle, J. (2006). Romancing Vietnam: Inside The Boat Country, 2nd Edition. Oxford: Signal book, xix+449pp.

Zhang, L. (2008). "Socialism is Great!": A Worker's Memoir of The New China. Atlas and Company, New York, 57pp.

Zhou, Z. \& Z. Jiang (2005). Identifying snake species threatened by economic exploitation and international trade in China. Biodiversity and Conservation 14(14): 3525-3536.

Ziegler, T. (2004). Research of the species diversity in the Vietnam project of Cologne Zoo: the amphibians and reptiles of Phong Nha-Ke Bang. Zeitschrift des Koelner Zoo 47(4): 147-171.

Ziegler, T., V.S. Nguyen \& Q.T. Nguyen, (2008). A new reed snake Calamaria Boie (Squamata: Colubridae), from Vietnam. Current Herpetology 27(2): 71-80 